\title{
ANALISIS PENGARUH PDRB, TINGKAT PENGANGGURAN, DAN IPM TERHADAP TINGKAT KEMISKINAN DI PROVINSI JAWA TENGAH
}

\author{
Ridho Andykha \\ Email : ridhoanputra@gmail.com \\ Herniwati Retno Handayani \\ Email : noniar@yahoo.com \\ Nenik Woyanti \\ Departemen IESP Fakultas Ekonomika dan Bisnis Universitas Diponegoro \\ Email :neniwoyanti346@gmail.com
}

Received: April 2018; Accepted: May 2018; Available online: July 2018

\begin{abstract}
Abstrak
Tingginya tingkat kemiskinan di Jawa Tengah menunjukkan proses pembangunan ekonomi yang belum bisa meningkatkan kesejahteraan masyarakat secara merata. Dengan demikian, diperlukan adanya analisis untuk mengetahui faktor-faktor yang mempengaruhi kemiskinan dalam rangka mengatasi kemiskinan. Tujuan dari penelitian ini adalah menganalisis Produk Domestik Regional Bruto (PDRB), Tingkat Kemiskinan, Indeks Pembangunan Manusia (IPM) terhadap kemiskinan pada 35 Kabupaten/Kota di Provinsi Jawa Tengah dari tahun 2011 hingga 2015. Penelitian ini menggunakan data sekunder dengan data cross-section terdiri dari 35 Kabupaten/Kota di Provinsi Jawa Tengah dan data time-series yaitu tahun 2011-2015. Alat analisis yang digunakan dalam mengestimasi model regresi data panel yaitu Fixed Effect Model (FEM) atau disebut juga Least Square Dummy Variable. Hasil penelitian menunjukkan bahwa variabel laju pertumbuhan PDRB berpengaruh positif dan signifikan terhadap Tingkat Kemiskinan. IPM berpengaruh negatif dan signifikan terhadap Tingkat Kemiskinan. Sedangkan Tingkat Pengangguran Terbuka berpengaruh positif dan signifikan terhadap Tingkat Kemiskinan. Berdasar hasil penelitian maka pemerintah disarankan untuk melakukan koordinasi dengan dinas terkait dalam merumuskan kebijakan peningkatan kualitas pendidikan dan pengoptimalan pelayanan kesehatan.
\end{abstract}

Kata kunci: Kemiskinan, Laju Pertumbuhan PDRB, Indeks Pembangunan manusia (IPM), Pengangguran, Fixed Effect Model

\begin{abstract}
The high level of poverty in Central Java shows unreliable development that still cannot increase prosperity equally. Hence, analysis is required to identify several factor that affect. This research's purpose is to identify Gross Domestic Regional Product (GDRP), Unemployment Level, Human Development Index (HDI) that affect the poverty level of the poverty level of 35 Districts/Cities of Central Java Province from 2011 until 2016. This research uses secondary data containing 35 Districts/Cities of Central Java on cross section data and 2011 until 2016 on time series data. The analytical method of this research is Fixed Effect Model (FEM) or Least Square Dummy Variable (LSDV). The results of this research show that Growth of GDRP gives positive and significant effect for poverty level. HDI give negative and significant effect for poverty level. On the other side, Unemployment Level give positive and significant effect for poverty level. Based on the results of the research, the government is advised to coordinate with relevant agencies in formulating policies to improve the quality of education and optimize health services.

Keyword: Poverty, Growth of Domestic Regional Product (GDRP), Human Development Index (HDI), Unemployment, Fixed Effect Model
\end{abstract}

How to Cite: Andykha, R., Handayani, H. R., \& Woyanti, N. (2018). Analisis Pengaruh PDRB, Tingkat Pengangguran, dan IPM Terhadap Tingkat Kemiskinan di Provinsi Jawa Tengah. Media Ekonomi dan Manajemen, 33(2), 113-123. 


\section{Pendahuluan}

Salah satu tujuan pembangunan nasional Indonesia berdasarkan Pembukaan Undang-Undang Dasar 1945 yaitu memajukan kesejahteraan umum. Kesejahteraan umum merupakan kondisi terpenuhinya kebutuhan material, spiritual, dan sosial penduduk negara agar dapat hidup layak dan mampu mengembangkan diri, sehingga dapat melaksanakan fungsi sosial dan ekonominya. Kesejahteraan umum di Indonesia dapat digambarkan salah satunya berdasarkan tingkat kemiskinan. Terdapat hubungan negatif antara kesejahteraan umum dengan tingkat kemiskinan di Indonesia. Semakin rendah tingkat kemiskinan menggambarkan semakin tinggi kesejahteraan penduduk.

Nurkse (2006) menjelaskan dua lingkaran perangkap kemiskinan dari segi penawaran (supply) dan permintaan (demand). Segi penawaran menjelaskan bahwa tingkat pendapatan masyarakat yang rendah akibat tingkat produktivitas rendah menyebabkan kemampuan masyarakat untuk menabung rendah. Rendahnya kemampuan menabung masyarakat menyebabkan tingkat pembentukan modal (investasi) rendah, sehingga terjadi kekurangan modal dan dengan demikian tingkat produktivitas juga akan rendah. Begitu seterusnya. Sedangkan dari segi permintaan menjelaskan di negara-negara yang miskin rangsangan untuk menanamkan modal sangat rendah karena keterbatasan luas pasar untuk berbagai jenis barang. Hal ini disebabkan pendapatan masyarakat yang sangat rendah karena tingkat produktivitasnya yang juga rendah, sebagai akibat dari tingkat pembentukan modal yang terbatas di masa lalu. Pembentukan modal yang terbatas ini disebabkan kekurangan rangsangan untuk menanamkan modal.

Permasalahan kemiskinan merupakan masalah yang kompleks dan bersifat multidimensional oleh karena itu, upaya pengentasan kemiskinan harus dilakukan secara komprehensif, mencakup berbagai aspek kehidupan masyarakat, dan dilaksanakan secara terpadu (Nasir, 2008). Upaya penanggulangan kemiskinan di Jawa tengah dilaksanakan melalui lima pilar yang disebut "Grand Strategy". Pertama, perluasan kesempatan kerja, ditujukan untuk menciptakan kondisi dan lingkungan ekonomi, politik, dan sosial yang memungkinkan masyarakat miskin dapat memperoleh kesempatan dalam pemenuhan hak-hak dasar dan peningkatan taraf hidup secara berkelanjutan. Kedua, pemberdayaan masyarakat, dilakukan untuk mempercepat kelembagaan sosial, politik, ekonomi, dan budaya masyarakat dan memperluas partisipasi masyarakat miskin dalam pengambilan keputusan kebijakan publik yang menjamin kehormatan, perlindungan, dan pemenuhan hak-hak dasar. Ketiga, peningkatan kapasitas, dilakukan untuk pengembangan kemampuan dasar dan kemampuan berusaha masyarakat miskin agar dapat memanfaatkan perkembangan lingkungan. Keempat, perlindungan sosial, dilakukan untuk memberikan perlindungan dan rasa aman bagi kelompok rentan dan masyarakat miskin baik laki-laki maupun perempuan yang disebabkan antara lain oleh bencana alam, dampak negatif krisis ekonomi, dan konflik sosial.

Menurut Todaro (2013) pertumbuhan penduduk dan pertumbuhan angkatan kerja secara tradisional dianggap sebagai salah satu faktor positif yang memacu pertumbuhan ekonomi. Jumlah tenaga kerja yang lebih besar berarti akan menambah tingkat produksi. Selanjutnya dikatakan bahwa pengaruh positif atau negatif dari pertumbuhan penduduk tergantung pada kemampuan sistem perekonomian daerah tersebut dalam menyerap dan secara produktif memanfaatkan pertambahan tenaga kerja tersebut.

Menurut Sukirno (2012) jumlah penduduk yang besar dalam pembangunan suatu daerah merupakan permasalahan mendasar. Karena pertumbuhan penduduk yang tidak terkendali dapat mengakibatkan tidak tercapainya tujuan pembangunan ekonomi yaitu kesejahteraan rakyat serta 
menekan angka kemiskinan. Perkembangan jumlah penduduk bisa menjadi faktor pendorong dan penghambat pembangunan.

Mariyanti dan Mahfudz (2016) yang melakukan penelitian mengenai hubungan pertumbuhan ekonomi dan kemiskinan, memperoleh hasil adanya hubungan kausalitas antara pertumbuhan ekonomi dan kemiskinan. Di sisi lain, Akoum (2008) dalam penelitiannya mengemukakan bahwa negara dengan pertumbuhan ekonomi yang tinggi memiliki tingkat kemiskinan yang juga tinggi. Sedangkan Prasad (1998) berpendapat bahwa tidak ditemukan hubungan yang kongkret antara pertumbuhan ekonomi dan kemiskinan

Kualitas sumber daya manusia juga dapat menjadi faktor penyebab terjadinya penduduk miskin. Kualitas sumber daya manusia dapat dilihat dari indeks kualitas hiudp/indeks pembangunan manusia. Rendahnya IPM akan berakibat pada rendahnya produktivitas kerja dari penduduk. Untuk menghasilkan manusia yang berkualitas diperlukan upaya-upaya untuk meningkatkan kualitas SDMnya. Adapun kualitas manusia dapat diukur melalui IPM. Menurut Mulyadi (2003) bahwa peningkatan kualitas manusia dapat dipenuhi dengan berbagai kebijakan, yaitu pembangunan pendidikan juga akan memperhatikan arah pembangunan ekonomi dimasa yang akan datang, pembangunan kesehatan harus mendapat perhatian dengan menanamkan budaya hidup sehat serta memperluas cakupan dan mutu pelayanan kesehatan, untuk penduduk miskin peningkatan kualitasnya dilakukan dengan memberikan keterampilan praktis.

Menurut Ginting (2008) pembangunan manusia di Indonesia identik dengan pengurangan kemiskinan. Investasi dibidang pendidikan dan kesehatan akan lebih berarti bagi penduduk miskin dibandingkan penduduk tidak miskin, karena aset utama penduduk miskin adalah tenaga kasar. Tersedianya fasilitas pendidikan dan kesehatan murah akan sangat membantu untuk meningkatkan produktivitas masyarakat

Dalam penelitiannya, Hong dan Pandey (2007) memperoleh hasil yaitu penduduk dengan tingkat pendidikan yang lebih tinggi memiliki kemungkinan yang lebih kecil untuk menjadi miskin. Ele-Ojo Ataguba et al. (2013) dalam penelitiannya mengemukakan bahwa salah satu penentu penurunan tingkat kemiskinan ialah pendidikan.

Penelitian Suliswanto (2010) mengenai pengaruh Produk Domestik Bruto (PDB ) dan Indeks Pembangunan Manusia (IPM) terhadap angka kemiskinan di Indonesia menjelaskan bahwa IPM berpengaruh negatif dan signifikan. Penelitian Saputra (20110) mengenai analisis pengaruh jumlah penduduk, PDRB, IPM, pengangguran terhadap tingkat kemiskinan di Kabupaten/Kota Jawa Tengah pada tahun 2011 menejelaskan bahwa IPM berpengaruh negatif terhadap tingkat kemiskinan.

Tujuan penelitian ini yaitu menganalisis bagaimana pengaruh PDRB, Tingkat pengangguran, dan IPM terhadap Tingkat kemiskinan di Provinsi Jawa Tengah (2011-2016).

\section{METODE PENELITIAN}

Penelitian ini menggunakan empat variabel, yaitu terdiri dari satu variabel dependen dan empat variabel independen. Tingkat kemiskinan (P) Jawa Tengah sebagai variabel dependen, selanjutnya variabel independen dalam penelitian ini meliputi laju pertumbuhan PDRB (Y), tingkat pengangguran (U), IPM (I) dari setiap wilayah 34 kabupaten/kota di Provinsi Jawa Tengah. Adanya definisi operasional berfungsi untuk memperjelas dan memudahkan dalam memahami penggunaan variabel-variabel yang akan dianalisis dalam penelitian ini.

Definisi operasional tersebut sebagai berikut.

Tingkat kemiskinan (P) adalah penduduk yang memiliki rata-rata 
pengeluaran per kapita per bulan berada di bawah garis kemiskinan (BPS, 2013). Variabel yang di pakai adalah Persentase Penduduk Miskin di masing-masing kabupaten/kota di Jawa Tengah tahun 2011-2015 dalam satuan persen (\%).

Laju pertumbuhan PDRB jumlah nilai barang dan jasa akhir (netto) yang dihasilkan oleh seluruh unit ekonomi (BPS, 2013).Variabel yang di pakai dalam penelitian adalah perubahan PDRB atas dasar harga konstan tahun 2010 di masingmasing kabupaten/kota di Jawa Tengah tahun 2011-2015 dalam satuan persen(\%).

IPM (I) dapat menerangkan bagaimana penduduk dapat mengakses pembangunan dalam memperoleh pendapatan, kesehatan dan pendidikan (BPS, 2016). IPM juga merupakan indikator yang penting untuk mengukur tingkat keberhasilan mengenai upaya membangun kualitas kehidupan manusia. Variabel yang di pakai dalam penelitian ini adalah IPM di masing-masing kabupaten/kota di Jawa Tengah tahun 2011-2015 dalam satuan persen (\%)./kota di Jawa Tengah tahun 2011-2015 dalam satuan persen $(\%)$.

Tingkat pengangguran terbuka (U) adalah angka yang menunjukkan banyaknya pengangguran (BPS, 2007), terhadap 100 penduduk yang masuk kategori angkatan kerja, dapat dihitung sebagai berikut :

Tingkat Pengangguran $=\frac{\text { Jumlah Pencari Kerja }}{\text { Jumlah Angkatan Kerja }} \times 100 \%$

Yang dipakai dalam penelitian ini adalah data Tingkat Pengangguran Terbuka masing-masing kabupaten/kota di Jawa Tengah tahun 2011-2015 dalam satuan persen $(\%)$.

\section{Metode Analisis}

Penelitian ini menggunakan analisis panel data (pooling data) yang diolah dengan menggunakan program Eviews 9. Analisis dengan menggunakan panel data adalah kombinasi antara deret waktu (time series) dan kerat lintang (cross section). Dalam model data panel persamaan model dengan menggunakan data cross-section dapat ditulis sebagai berikut:

$Y_{i}=\beta_{0}+\beta_{1} X_{i}+\mu_{i} ; i=1,2, \ldots, N$

dimana $\mathrm{N}$ adalah banyaknya data crosssection.

Sedangkan persamaan model dengan time series adalah

$\mathrm{Y}_{\mathrm{t}}=\beta_{0}+\beta_{1} \mathrm{X}_{\mathrm{t}}+\mu_{\mathrm{t}} ; \mathrm{t}=1,2, \ldots, \mathrm{T}$

dimana $\mathrm{T}$ adalah banyaknya data time series

Mengingat data panel merupakan gabungan dari time series dan crosssection, maka model dapat ditulis dengan:

$\mathrm{P}_{\mathrm{it}}=\alpha_{0}+\alpha_{1} \mathrm{Y}_{\mathrm{it}}+\alpha_{2} \mathrm{I}_{\mathrm{it}}+\alpha_{3} \mathrm{U}_{\mathrm{it}}+\mu_{\mathrm{it}} \ldots \ldots$...(3) Dimana $P_{i t}$ adalah tingkat kemiskinan, $\alpha_{0}$ adalah intersep, adalah koefisien regresi variabel bebas, $\mathrm{Y}$ adalah laju pertumbuhan PDRB Kabupaten/Kota di Jawa Tengah, U adalah tingkat pengangguran terbuka kabupaten/kota di Jawa Tengah, I adalah IPM tahunan kabupaten/kota di Jawa Tengah, dan $\mu$ merupakan error/variabel di luar model.

Selanjutnya terhadap hasil analisis regresi dengan model tersebut dilakukan pengujian ekonometrik dan uji statistik.

\section{Deteksi Asumsi Klasik}

Metode Ordinary Least Squares (OLS) merupakan model yang berusaha untuk meminimalkan penyimpangan hasil perhitungan (regresi) terhadap kondisi aktual. Dibandingkan dengan metode lain, Ordinary Least Squares merupakan metode sederhana yang dapat digunakan untuk melakukan regresi linear terhadap sebuah model. Sebagai estimator, Ordinary Least Squares merupakan metode regresi dengan keunggulan sebagai estimator linear terbaik yang tidak bias atau biasa dikenal dengan BLUE (Best Linear Unbiased Estimator), sehingga hasil perhitungan Ordinary Least Squares dapat dijadikan sebagai dasar pengambilan kebijakan. Namun, untuk menjadi sebuah estimator yang baik dan tidak bias, 
terdapat beberapa uji asumsi klasik yang harus dipenuhi.

Gujarati (2010) mengatakan bahwa kesepuluh asumsi yang harus dipenuhi. Pertama, model persamaan berupa linear. Kedua, nilai variabel independen tetap meskipun dalam pengambilan sampel yang berulang. Ketiga, nilai rata-rata penyimpangan sama dengan nol. Keempat, homoskedastisitas. Kelima, tidak ada autokorelasi antara variabel. Keenam, nilai covariance sama dengan nol. Ketujuh, jumlah observasi harus lebih besar daripada jumlah parameter yang diestimasi. Kedelapan, nilai variabel independen yang bervariasi. Kesembilan, model regresi harus memiliki bentuk yang jelas. Kesepuluh, adalah tidak adanya multikolinearitas antar variabel independen. Terpenuhinya kesepuluh asumsi di atas menjadikan hasil regresi memiliki derajat kepercayaan yang tinggi.

\section{Deteksi Normalitas}

Pendeteksian asumsi normalitas dilakukan untuk melihat apakah error term mengikuti distribusi normal. Jika asumsi tidak terpenuhi maka prosedur pengujian menggunakan uji - $t$ menjadi tidak sah. Pendeteksian dilakukan dengan Jarque Bera test atau dengan melihat plot dari sisaan. Adapun hipotesis dalam pendeteksian normalitas, yaitu:

$H_{0}$ : error term mengikuti distribusi normal

$H_{1}$ : error term tidak mengikuti distribusi normal.

Keputusan diambil dengan membandingkan nilai probabilitas Jarque Bera dengan taraf nyata $\alpha=0,05$. Jika nilai probabilitas Jarque Bera lebih dari $\alpha=0,05$ maka dapat disimpulkan bahwa error term terdistribusi dengan normal.

\section{Deteksi Heteroskedastisitas}

Heteroskedastisitas adalah suatu kondisi tidak terpenuhinya asumsi homoskedastisitas. Di dalam regresi linear berganda, salah satu asumsi yang harus dipenuhi agar taksiran parameter dalam model tersebut bersifat BLUE (Best, Linear, Unbiased Estimator) adalah $\left(\mu_{\mathrm{i}}\right)=$ $\mathrm{o}_{2}$ yang mempunyai variasi yang sama (homoskedastisitas). Pada kasus lain dimana $\mu \mathrm{i}$ tidak konstan disebut heteroskedastisitas. Untuk mendeteksi keberadaan heteroskedastisitas dapat dilakukan melalui Uji White.

Jika Chi-Square statistik lebih besar dari Chi-Square tabel, maka dapat dikatakan bahwa ada indikasi heteroskedastisitas. Pengujian dilakukan dengan cara membandingkan nilai $O b s^{*} R$-squared Uji White dengan nilai tingkat signifikansi $(\alpha=5 \%)$.

$\mathrm{H} 0$ : Homoskedastisitas

H1 : Heteroskedastisitas

Jika nilai $O b s^{*}$ Squared hitung lebih besar dibandingkan dengan nilai tingkat signifikansi $(\alpha=5 \%)$, maka model regresi terbebas dari gejala heterokedastisitas.

\section{Deteksi Multikolinearitas}

Multikolinearitas berarti adanya hubungan linear yang sempurna atau pasti di antara beberapa atau semua variabel independen dalam model regresi. Pada kasus multikolinearitas yang serius, koefisien regresi tidak lagi menunjukkan pengaruh murni dari variabel bebas dalam model. Metode yang digunakan dalam deteksi multikolinearitas ini adalah metode Klein dan kesepakatan Gujarati terhadap nilai korelasi antar variabel, yaitu dengan perbandingan antara $\mathrm{R}^{2}$ penyesuaian (adjusted $\mathrm{R}^{2}$ ) hasil regresi antar variabel bebas. Kemungkinan adanya multikolinearitas apabila Adjusted $R^{2}$ model deteksi variabel bebas lebih tinggi dari Adjusted $\mathrm{R}^{2}$ model utama. Indikasi lain terdapat gejala multikolinearitas adalah dengan menggunakan correlation matrics, di mana apabila correlation matrics lebih besar daripada 0,8 berarti terdapat gejala multikolinearitas, begitu juga sebaliknya.

\section{Uji Hausman}

Untuk menentukan secara tepat spesifikasi model yang akan digunakan apakah model fixed effect atau random effect maka dilakukan Uji Hausman untuk menguji model yang paling baik yang akan digunakan dalam estimasi. Uji Hausman akan memberikan penilaian dengan menggunakan Chi-Square Statistics 
sehingga keputusan pemilihan model dapat ditentukan secara benar. Penolakan terhadap statistik Hausman tersebut berarti penolakan terhadap fixed effect model atau dummy variable model, sehingga semakin besar nilai statistik Hausman tersebut semakin mengarah pada penerimaan dugaan error component model.

\section{Pengujian Parameter Model}

Pengujian parameter model bertujuan untuk mengetahui kelayakan model dan apakah koefisien yang diestimasi telah sesuai dengan teori atau hipotesis. Pengujian ini meliputi koefisien determinasi $\left(R^{2}\right)$, uji koefisien regresi parsial (uji t) dan uji koefisien regresi secara menyeluruh (F-test atau uji $\mathrm{F}$ ). Untuk model-model yang telah melewati uji signifikansi dan pendeteksian asumsi klasik baru dapat dipergunakan untuk uji hipotesis. Penjelasan dari uji yang dimaksud di atas adalah sebagai berikut.

\section{HASIL DAN PEMBAHASAN}

Provinsi Jawa Tengah meliputi 29 Kabupaten dan 6 kota, yaitu Kabupaten Cilacap, Kabupaten Cilacap, Banyumas, Purbalingga, Banjarnegara, Kebumen, Perworejo, Wonosobo, Magelang, Boyolali, Klaten, Sukoharjo, Wonogiri, Karanganyar, Sragen, Gobogan, Blora, Rembang Pati, Kudus, Jepara, Demak, Semarang, Temanggung, Kendal, Batang, Pekalongan, Pemalang, Tegal dan Brebes serta Kota Magelang, Surakarta, Salatiga, Semarang, Pekalongan, dan Tegal. Luas wilayah Jawa Tengah 3.254 .412 ha atau $25,4 \%$ dari luas pulau jawa dan setara $1,7 \%$ dari luas wilayah Indonesia. Berdasarkan hasil Sensus Ekonomi Nasional, jumlah penduduk Provinsi Jawa dari tahun 2010 hingga 2016 mengalami peningkatan.

Presentase Penduduk Miskin di setiap Kabupaten/Kota cenderung menurun dari tahun ke tahun. Sampai tahun 2016, Presentase Penduduk Miskin Provinsi Jawa Tengah sebesar 13,27\%. Kabupaten dengan Presentase Penduduk Miskin tertinggi pada tahun 2015 adalah
Kabupaten Wonosobo sebesar 20.53\%, sedangkan Kabupaten dengan Presentase Penduduk Miskin terendah ialah Kabupaten Kudus sebesar 7.65\%. Kota dengan Presentase Penduduk Miskin tertinggi adalah Kota Surakarta sebesar 10,88\%, sedangkan Kota Semarang mempunyai Presentase Penduduk Miskin terendah sebesar $4.85 \%$.

PDRB Provinsi Jawa Tengah selalu mengalami peningkatan dari tahun ke tahun. Produk Domestik Regional Bruto 35 Kabupaten/Kota di Jawa Tengah dari tahun 2011 hingga 2016. Kabupaten dengan ratarata laju pertumbuhan PDRB tertinggi adalah Kabupaten Blora sebesar 23.3\%, sedangkan yang terendah yaitu Kabupaten Kudus sebesar 2,42\%. Kota dengan laju pertumbuhan PDRB tertinggi adalah Kota Semarang sebesar 5.69\%, sedangkan yang terendah yaitu Kota Magelang sebesar $5,17 \%$.

Tingkat Pengangguran Terbuka 29 Kabupaten dan 6 Kota di Provinsi Jawa Tengah tahun 2011 hingga 2016. Kabupaten dengan rata-rata Tingkat Pengangguran Terbuka paling rendah adalah Kabupaten Temanggung sebesar $3,24 \%$, sedangkan yang tertinggi yaitu Kabupaten Brebes sebesar 8,99\%. Dengan kata lain, $8,83 \%$ penduduk usia kerja Kabupaten Brebes belum bekerja. Kota dengan rata-rata Tingkat Penganguran Terbuka terendah yaitu Kota Pekalongan sebesar $5,93 \%$, sedangkan yang tertinggi adalah Kota Tegal sebesar $8,88 \%$. Artinya $8,88 \%$ penduduk usia kerja Kota Tegal belum bekerja.

Indeks Pembangunan Manusia pada tiap Kabupaten/Kota di Provinsi Jawa Tengah secara spesifik pada 29 Kabupaten dan 6 Kota cenderung mengalami peningkatan dari tahun 2011-2016. Pada tahun 2016, Kabupaten dengan Indeks Pembangunan Manusia terendah adalah Kabupaten Brebes sebesar 63,98, sedangkan Kabupaten dengan Indeks Pembangunan Tertinggi adalah Kabupaten Sukoharjo sebesar 75,06\%. Kota dengan Indeks Pembangunan Manusia tertinggi 
adalah Kota Semarang sesbasr 81.19\%, sedangkan Kota Pekalongan dengan Indeks Pembangunan Manusia terendah sebesar 73,32\%

\section{Deteksi Normalitas}

Uji normalitas dilakukan dengan tujuan untuk melihat apakah error term terdistribusi secara normal. Uji Normalitas dilakukan dengan melihat probabilitas Jarque-Bera. Jika probabilitas Jarque-Bera lebih besar dari $\alpha=5 \%$, maka dapat dikatakan bahwa error term terdistribusi normal. Berdasarkan hasil uji normalitas, dengan melihat nilai probabilitas JarqueBera sebesar 15,73 pada $\alpha=5 \%$, dapat dikatakan bahwa error term terdistribusi secara normal karena probabilitas JarqueBera lebih besar dari $\alpha=5 \%$

\section{Deteksi Heteroskedastisitas}

Pengujian Heteroskedatisitas bertujuan untuk menguji apakah dalam model regresi terjadi ketidaksamaan variance dari residual satu pengamatan ke pengamatan lain. Jika variance dari residual satu pengamatan ke pengamatan lain tetap, maka disebut homoskedatisitas dan jika berbeda disebut heteroskedatisitas. Model regresi yang baik adalah yang homoskedatisitas atau tidak terjadi heteroskedatisitas (Ghozali, 2016). Berdasarkan hasil pada tabel Uji White, nilai Chi-Square statistik sebesar 0,141 lebih besar dari $\alpha=5 \%$. Nilai $O b s^{*} R$ squared statistik sebesar 9,703 lebih kecil dari $O b s * R$-squared hitung tabel yaitu sebesar 124,342 atau nilai probabilitasnya lebih dari 0,05. Dengan kata lain model regresi dalam penelitian tidak mengalami heteroskedastisitas.

\section{Deteksi Multikolinearitas}

Sebuah model regresi yang tergolong baik ialah tidak ada korelasi yang kuat antar variabel independen dalam model tersebut. Model regresi mengalami multikolinearitas ketika dua atau lebih variabel independen dalam model tersebut memiliki korelasi yang kuat. Salah satu cara mendeteksi multikolinearitas adalah dengan menggunakan correlation matrics, di mana apabila correlation matrics lebih besar daripada 0,8 berarti terdapat gejala multikolinearitas. Berdasarkan hasi Correlation Matrics, koefisien variabel kemiskinan dengan IPM sebesar -0.466, dengan variabel PDRB sebesar -0,026, dengan variabel pengangguran sebesar 0,038. Besarnya koefisien korelasi antar variabel independen dalam model regresi lebih kecil dari 0,8. Dengan kata lain, model regresi dalam penelitian tidak mengalami multikolinearitas.

\section{Uji Koefisien Determinasi}

Koefisien determinasi $\left(\mathrm{R}^{2}\right)$ digunakan untuk mengukur seberapa jauh kemampuan model dalam menerangkan variasi variabel dependen. Nilai koefisien determinasi adalah nol sampai satu. Nilai $\left(\mathrm{R}^{2}\right)$ yang kecil berarti kemampuan variabel-variabel independen dalam menjelaskan variasi variabel dependen sangat terbatas. Sementara itu, nilai $\left(\mathrm{R}^{2}\right)$ yang mendekati satu berarti variabelvariabel independen memberikan hampir semua informasi yang dibutuhkan untuk memprediksi variasi variabel dependen atau dengan kata lain variabel-variabel independen dalam model mampu menjelaskan variasi variabel dependen dengan sangat sesuai. Nilai R-Squared sebesar 0,96 pada tabel mengandung arti bahwa 98,1\% variabel Tingkat Kemiskinan dapat dijelaskan oleh variabel PDRB,IPM dan Pengangguran. Sedangkan sisanya $0.4 \%$ kemiskinan dapat di jelaskan oleh variabel lain yang tidak dimasukkan dalam model analisis penelitian ini

\section{Uji Signifikansi Simultan (Uji F)}

Uji $F$ digunakan untuk menunjukkan pengaruh (signifikansi) variabel independen yang dimasukkan dalam model secara bersama-sama (simultan) terhadap variabel tak bebas. Nilai $F$ statistik dapat dihitung dengan melihat nilai dari $\mathrm{F}$ tabel. Pada penelitian ini hasil estimasi PDRB, IPM dan Pengangguran terhadap Tingkat Kemiskinan tahun 2011-2016 dengan taraf keyakinan $95 \%$, degree of freedom for numerator $=4(\mathrm{k}-1)$ dan degree of freedom for denominator $=5$ diperoleh nilai $\mathrm{F}$ tabel sebesar 4,40. Berdasarkan hasil regresi, 
diperoleh nilai $\mathrm{F}$ statistik sebesar 127.5955. Dengan kata lain, variabel DPRB, IPM dan Pengangguran secara simultan berpengaruh terhadap variabel Tingkat Kemiskinan Jawa Tengah.

\section{Uji signifikansi Parsial (Uji t)}

Uji statistik $t$ menunjukkan seberapa besar pengaruh masing-masing variabel independen secara individual dalam menerangkan variabel dependen. Pada penelitian ini, nilai degree of freedom $=175(\mathrm{n}-\mathrm{k}=180-5)$, maka diperoleh nilai $\mathrm{t}$ tabel dengan $\alpha=5 \%$ sebesar 1,980. Berdasarkan hasil uji signifikansi parsial, nilai $\mathrm{t}$ statistik variabel PDRB adalah sebesar 1.636, nilai $t$ statistik variabel IPM adalah sebesar -11,194 dan nilai t statistik variabel Pengangguran adalah sebesar 4,620. Sehingga dapat disimpulkan bahwa variabel PDRB, IPM dan Pengangguran beperngaruh signifikan secara parsial terhadap Tingkat Kemiskinan di Jawa Tengah.

Berdasarkan hasil olahan komputer dengan menggunakan bantuan software Eviews 9.0. didapat hasil uji yang ditunjukkan pada Tabel 1.

Berdasarkan hasil pengolahan data pada Tabel 1 diperoleh bentuk persamaan sebagai berikut:

Pit $=385.6173+0.160666$ PDRB + 0.229597 Pengangguran - 5.02771 IPM

Model regresi dalam penelitian ini telah memenuhi asumsi klasik, yaitu BLUE (Best Linear Unbiased Estimate). Variabel independen dalam model, yaitu laju pertumbuhan PDRB, Pendidikan, Kesehatan, dan Pengangguran berpengaruh terhadap Tingkat Kemiskinan secara signifikan $(\alpha=5 \%)$. Hasil uji koefisien determinasi menunjukkan angka sebesar 0,9878. Sehingga dapat dikatakan bahwa sebanyak 96,48\% variasi Tingkat Kemiskinan dapat dijelaskan oleh variasi laju pertumbuhan PDRB, Pendidikan, Kesehatan, dan Pengangguran sedangkan
$3,52 \%$ dijelaskan oleh variabel lain di luar model.

PDRB memiliki pengaruh yang positif dan signifikan terhadap Tingkat Kemiskinan di Provinsi Jawa Tengah. Berdasarkan hasil regresi, koefisien PDRB adalah sebesar 0,160. Hasil Persamaan menunjukan bahwa variabel PDRB berpengaruh positif dan signifikan. Artinya ketika PDRB semakin besar maka Tingkat Kemiskinan akan semakin besar. Sejalan dengan hasil penelitian, teori kemiskinan relatif yang dikemukakan oleh Miller (dalam Arsyad, 2010) menyatakan bahwa garis kemiskinan akan berubah apabila kondisi perekonomian masyarakat meningkat yang di sebabkan oleh inflasi, sehingga kemiskinan akan selalu ada.

IPM memiliki pengaruh negatif dan signifikan terhadap tingkat kemiskinan Provinsi Jawa Tengah. Berdasarkan hasil regresi, nilai koefisien IPM adalah sebesar -5,027. Artinya setiap kenaikan 1 tahun pada IPM akan memberikan dampak turunnya Tingkat Kemiskinan sebesar $5,027 \%$.Hasil penelitian ini sejalan dengan penelitian Bakhtiari dan Meisami (2009) yang menyatakan bahwa adanya peningkatan di bidang pendidikan akan menurunkan tingkat kemiskinan. Sejalan dengan Bakhtiari dan Meisami, penelitian yang dilakukan oleh Ataguba dkk. (2013) juga memperoleh hasil yang menyatakan bahwa salah satu faktor penentu menurunnya tingkat kemiskinan ialah pendidikan.

Pengangguran yang direpresentasikan oleh Tingkat Pengangguran Terbuka (TPT) memiliki pengaruh yang positif dan signifikan terhadap Tingkat Kemiskinan Provinsi Jawa Tengah. Berdasarkan hasil regresi, nilai koefisien Pengangguran adalah sebesar 0,229. Artinya setiap kenaikan Tingkat Pengangguran Terbuka sebesar 1\% akan memberikan dampak naiknya Tingkat Kemiskinan sebesar 0,229 . Hasil penelitian ini sesuai dengan penelitian Hong dan Pandey (2007) yang menyatakan bahwa pengangguran berpengaruh secara positif dan terhadap 
kemiskinan. Hasil yang sama juga diperoleh Ukpere dan Slabbert (2009) yaitu pengangguran di era globalisasi berpengaruh secara positif dan signifikan terhadap kemiskinan. Hasil ini dapat diartikan bahwa ketika tingkat pengangguran naik, tingkat kemiskinan juga akan meningkat.

Tabel 1. Hasil Pengolahan Komputer Data Penelitian

\begin{tabular}{|c|c|c|c|c|c|}
\hline Variable & Coefficient & Std. Error & t-Statistic & Prob. & Keterangan \\
\hline $\mathrm{C}$ & 385.6173 & 33.45192 & 11.52751 & 0 & Signifikan \\
\hline PDRB & 0.160666 & 0.0982 & 1.636122 & 0.1041 & Tidak Signifikan \\
\hline PENGANGGURAN & 0.229597 & 0.049689 & 4.620656 & 0 & Signifikan \\
\hline IPM & -5.02771 & 0.449118 & -11.1946 & 0 & Signifikan \\
\hline F-statistic & & & & & 127.5955 \\
\hline Prob(F-statistic) & & & & & 0 \\
\hline R-Squared & & & & & 0.964848 \\
\hline CROSSID & Effect & & CROSSID & & Effect \\
\hline 1 & -6.78 & & 19 & & 4.73 \\
\hline 2 & -2.65 & & 20 & & 1.84 \\
\hline 3 & -1.15 & & 21 & & 5.90 \\
\hline 4 & 0.11 & & 22 & & 0.77 \\
\hline 5 & -0.73 & & 23 & & 3.65 \\
\hline 6 & -0.97 & & 24 & & -2.83 \\
\hline 7 & -9.50 & & 25 & & -2.04 \\
\hline 8 & -6.08 & & 26 & & -5.80 \\
\hline 9 & 5.69 & & 27 & & -3.93 \\
\hline 10 & 12.90 & & 28 & & -22.45 \\
\hline 11 & 11.43 & & 29 & & -26.82 \\
\hline 12 & 7.85 & & 30 & & 6.23 \\
\hline 13 & 12.05 & & 31 & & 10.60 \\
\hline 14 & 6.46 & & 32 & & 3.57 \\
\hline 15 & -0.08 & & 33 & & 5.13 \\
\hline 16 & -2.18 & & 34 & & -6.89 \\
\hline 17 & 6.02 & & 35 & & -7.03 \\
\hline 18 & 3.81 & & 36 & & -4.10 \\
\hline
\end{tabular}

\section{PENUTUP}

\section{Kesimpulan}

PDRB berpengaruh positif terhadap

Tingkat Kemiskinan pada 35 Kabupaten/Kota di Provinsi Jawa Tengah. Hasil ini mengindikasikan pertumbuhan ekonomi tidak merata dan didominasi oleh kontribusi masyarakat golongan berpendapatan tinggi. Pertumbuhan ekonomi yang tidak diikuti oleh pemerataan akan mengakibatkan ketim- pangan ekonomi pada suatu daerah. Berdasarkan pada hasil penelitian, variabel Pengangguran yang direpresentasikan oleh Tingkat Pengangguran Terbuka (TPT) berpengaruh secara positif dan signifikan terhadap Tingkat Kemiskinan pada 35 Kabupaten/Kota di Provinsi Jawa Tengah. Hasil ini sesuai dengan pendapat Todaro yang menyatakan bahwa adanya permasalahan pengangguran berkaitan erat dengan kemakmuran masyarakat. Pening- 
katan kesempatan kerja melalui perluasan lapangan kerja akan mengurangi tingkat pengangguran, sehingga tingkat kemakmuran masyarakat meningkat. IPM yang direpresentasikan oleh IPM tahunan berpengaruh secara negatif terhadap tingkat Kemiskinan pada 35 Kabupaten/Kota di Provinsi Jawa Tengah. IPM berkaitan dengan produktivitas. IPM yang baik akan meningkatkan daya kerja sehingga akan meningkatkan output.

\section{Saran}

Pendidikan formal merupakan pionir dalam pembentukan modal manusia yang berkualitas. Pemerintah diharapkan dapat melakukan koordinasi dengan dinas terkait dalam merumuskan kebijakan yang meningkatkan kualitas pendidikan di Jawa Tengah. Kualitas tersebut tidak hanya berkaitan dengan sarana seperti sekolah atau guru, namun juga kemudahan masyarakat dalam mengakses pendidikan yang nantinya dapat digunakan sebagai modal dalam meningkatkan kesejahteraan. Pemerintah Provinsi Jawa Tengah diharapkan dapat melakukan koordinasi dengan instansi terkait dalam mengoptimalkan pelayanan kesehatan sehingga masyarakat dapat mengaksesnya dengan mudah, terutama bagi masyarakat kurang mampu.

\section{DAFTAR PUSTAKA}

Akoum, I. F. (2008). Globalization, growth, and poverty: the missing link. International Journal of Social Economics, 35(4), 226-238.

Bakhtiari, S., \& Meisami, H. (2010). An empirical investigation of the effects of health and education on income distribution and poverty in Islamic countries. International Journal of Social Economics, 37(4), 293-301.
Ele-Ojo Ataguba, J., Eme Ichoku, H., \& Fonta, W. M. (2013). Multidimensional poverty assessment: applying the capability approach. International Journal of Social Economics, 40(4), 331-354.

Ginting, S., Kuriata, C. (2008), Pembangunan Manusia di Indonesia dan Faktor-Faktor yang Mempengaruhinya. Jurnal Perencanaan dan Pembangunan Wilayah. 4(1).

Gujarati, D., \& Porter, D.C. 2010. Basic Econometrics. New York: McGraw Hill.

Mariyanti, T., \& Mahfudz, A. A. (2016). Dynamic circular causation model in poverty alleviation: Empirical evidence from Indonesia. Humanomics, 32(3), 275-299.

Mulyadi. (2012). Ekonomi Sumber Daya Manusia dalam Perspektif Pembangunan. Jakarta. Raja Grafindo Persada.

Nasir, M. (2008). Analisis Faktor-Faktor Yang Mempengaruhi Kemiskinan Rumah Tangga Di Kabupaten Purworejo. Jurnal Eksekutif. 5(4).

Nurkse, R. (2006). Problems of Capital Formation in Underdeveloped Countries. Oxford Basis Blackwell.

Prasad, B. C. (1998). The woes of economic reform: poverty and income inequality in Fiji. International Journal of Social Economics, 25(6/7/8), 1073-1094.

Saputra, W. A., \& Mudakir, Y. B. (2011). Analisis Pengaruh Jumlah Penduduk, PDRB, IPM, Pengangguran Terhadap Tingkat Kemiskinan di Kabupaten/Kota Jawa Tengah (Doctoral dissertation, Universitas Diponegoro). 
Sukirno, S. (2012). Makroekonomi: Teori Pengantar. Jakarta. Raja Grafindo Persada.

Suliswanto, M.S.W. (2010). Pengaruh produk domestik bruto (PDB) dan indeks pembangunan manusia (IPM) terhadap angka kemiskinan di Indonesia. Jurnal Ekonomi Pembangunan, 8(2), 357-366.

Todaro, M.P. (2013). Pembangunan Ekonomi. Jakarta: Penerbit Erlangga.

Young P. Hong, P., \& Pandey, S. (2007). Human capital as structural vulnerability of US poverty. Equal Opportunities International, 26(1), 18-43. 